\title{
Production of Indigoid Pigments by Persolvent Fermentation with Pseudomonas putida BCNU 106
}

\author{
Hye Jung Choi', Gi-Seok Kwon ${ }^{2}$ and Woo Hong Joo'* \\ ${ }^{1}$ Department of Biology and Interdisciplinary Program for Biotechnology, Changwon National University, Changwon 641-773, Korea \\ ${ }^{2}$ School of Bioresource Science, Andong National University, Andong 760-749, Korea
}

Received October 23, 2013 /Revised December 2, 2013 /Accepted December 11, 2013

\begin{abstract}
Pseudomonas sp. BCNU 106 isolated from industrial wastewater was able to produce indigo from indole by utilizing various organic solvents. BCNU 106 produced indigo effectively when grown in the presence of a large volume of pxylene, propylbenzene, and mesitylene and a high level of indole. The present study demonstrated that the maximal yield was achieved with $20 \%(\mathrm{v} / \mathrm{w})$ pxylene and $4 \mathrm{~g} / \mathrm{l}$ indole. Under these conditions, the indigo yield and the transformation efficiency of indole were $315.5 \mathrm{mg} / \mathrm{l}$ and $97 \%$, respectively. The results suggest that Pseudomonas sp. BCNU 106 might be a potential candidate for industrially important indigo production.
\end{abstract}

Key words : Biotransformation, indigoid pigments, microbial biosynthesis, Pseudomonas sp.

\section{서 론}

Indigo는 가장 광범위하게 사용되어온 청색 염료 가운데 하나로 전통적으로는 Polygonum tinctorium, Indiofera tinctoria 및 Isatis indigotica 등 식물에서 추출하여 사용하였다 $[1,5]$. 그 러나 이들 식물에서 생산되는 인디고는 대량 생산이 어렵고 추출에 어려움이 있어 주로 화학적인 방법에 의해 대량생산되 고 있으며, 이 과정은 고밀도 $\mathrm{COD}$ 와 aniline, nitrobenzene 그리고 금속염과 같은 환경오염물질을 발생시키고, 고에너지 가 요구된다[13]. 따라서 현재는 친환경적이면서 경제적인 방 법으로 indigo를 생산하기 위해 미생물을 이용하려는 연구가 이루어지고 있다. 미생물에 의한 indigo 생산은 naphthalene dioxygenase를 발현하는 E. coli에서 처음 보고되었으며[9], 그 이후 Pseudomanas sp. 및 Acinetobacter sp. 균주에서 indigo 생 산에 관해 다수 보고가 되고 있다 $[3,7]$. 이들 indigo 생산 균주 들은 탄소원과 에너지원으로 방향족 화합물을 이용하여 기질 인 indole 및 tryptophan으로부터 indigo 생산을 촉매하는 oxygenase를 발현하는 것으로 알려져 있어, indigo 생산뿐만 아니라 다양한 생물변환반응에도 적용 가능하여 유용성이 높 은 균주로 보고되고 있다[9, 16].

따라서 본 연구에서는 indole을 기질로 indigo를 생산하는 유기용매 내성 Pseudomonas sp. BCNU 106 균주[4]를 이용하

\footnotetext{
*Corresponding author

Tel : +82-82-55-213-3453, Fax : +82-82-55-213-3459

E-mail : whjoo@changwon.ac.kr

This is an Open-Access article distributed under the terms of the Creative Commons Attribution Non-Commercial License (http://creativecommons.org/licenses/by-nc/3.0) which permits unrestricted non-commercial use, distribution, and reproduction in any medium, provided the original work is properly cited.
}

여 다양한 방향족 화합물과 indole에 대한 생존력을 조사하였 으며, 이들 결과를 바탕으로 indigo 및 indirubin 전환율에 대 해 조사하여 보고하고자 한다.

\section{재료 및 방법}

Indigo 생산 균주의 배양조건

대구공단 일대에서 채취한 폐수 및 토양 시료에서 분리한 toluene 내성 세균인 Pseudomonas sp. BCNU 106 균주를 사용 하여 indigo 생산여부를 확인하였다. BCNU 106 균주의 전배 양은 LB (tryptone $1 \%$, yeast extract $0.5 \%, \mathrm{NaCl} 1 \%$ ) 배지를 이용하였고, indigo 및 유도체 생산은 conversion medium (Bacto yeast extract $0.2 \%, \mathrm{NaCl} 1 \%,\left(\mathrm{NH}_{4}\right)_{2} \mathrm{SO}_{4} 0.05 \%, \mathrm{MgSO}_{4}$ $10 \mathrm{mM}$ )을 사용하여, $30^{\circ} \mathrm{C}, 160 \mathrm{rpm}$ 에서 배양하였다[6].

\section{Two-phase system에서의 생존력 조사}

전배양한 균 배양액 $\left({\left.\mathrm{O} . \mathrm{D}_{600}=1\right)} 1 \mathrm{ml}\right.$ 는 원심분리 $(8,000 \mathrm{rpm}$, $10 \mathrm{~min}$ )하고 2번 washing 후, $10 \mathrm{ml}$ conversion medium에 접종하였다. 기질로서 다양한 농도의 Indole $(5-320 \mathrm{mg})$ 을 첨 가하였고, 5 종의 유기용매( $p$ xylene, diphenylmethane, propylbenzene, toluene, mesitylene)는 배지의 $20 \%$ 로 중층한 후 $30^{\circ} \mathrm{C}, 160 \mathrm{rpm}$ 에서 24 시간 배양한 뒤에 흡광도 $(\mathrm{OD} 600)$ 를 측정함으로써 생존력을 확인하였다.

\section{Indigo 및 indirubin 전환율 조사}

다양한 농도의 indole과 $20 \%(\mathrm{v} / \mathrm{w})$ 의 유기용매를 첨가한 two-phase system에서 24 시간 배양한 후, 원심분리(10,000 $\mathrm{rpm}, 10 \mathrm{~min}$ )하여 배지층과 용매층을 분리하였다. 배지층을 사용하여 필터 $(0.22 \mu \mathrm{m})$ 한 후 동량의 ethylaceteate로 추출하 
고 $\mathrm{N}_{2}$

gas로 농축한 뒤 indole 소비량과 isatin 생산량을 측정하였고, 용매층을 사용하여 무수 $\mathrm{MgSO}_{4}$ 를 첨가하여 탈수시키고, 농축 하여 indigo와 indirubin 생산량을 측정하였다 [14, 15]. Indole, indigo, indirubin 및 isatin은 high performance liquid chromatography (HPLC; Shimadzu, Japan)로 ODS-1201-H column $(200 \times 4.6 \mathrm{~mm})$ 을 사용하여, 이동상으로는 acetonitrile과 $0.15 \%$ formic acid (30 to 50:50 to $70 \mathrm{v} / \mathrm{v}$ ) 를, flow rate는 0.6 $\mathrm{ml} / \mathrm{min}$ 조건으로 분석하였다. Indole, indigo 및 isatin은 Sigma-Aldrich에서 구입하였고, indirubin은 Biomol (Biomol Research Laboratories, Plymouth Meeting, PA, USA)에서 구 입하였다. PDA detector를 이용하여 시료주입량을 $20 \mu 1$ 로 하 여 동일 조건 하에서 표준물질과 비교하여 indole 소비량과 indigo, indirubin과 isatin 생산량을 각각의 최대 흡수 파장 (indole, $\mathrm{A}_{270}$; indigo, $\mathrm{A}_{612}$ i indirubin, $\mathrm{A}_{542} ;$ isatin, $\mathrm{A}_{412}$ )에서 정량 분석하였다.

\section{결과 및 고찰}

대구공단 지역의 토양 및 폐수에서 분리한 Pseudomonas sp. $\mathrm{BCNU} 106$ 은 기연구에서 생리·생화학적 특징 및 염기서열 분 석을 통해 Pseudomonas putida의 근연종이며, BTEX (benzene, toluene, ethylbenzene, xylene)을 포함한 다양한 유기용매에 내성이 높은 세균으로 확인되었다[4]. 본 연구에서는 indole을 기질로 사용하여 indigo 및 그 유도체를 생합성하는 능력 또한 뛰어난 균주임이 확인되었다. $20 \%$ 의 유기용매로 중층한 최소 배지에 0.5-32 g/1의 indole을 첨가하여 24 시간 배양하여 $\mathrm{BCNU} 106$ 의 생존력을 조사한 결과, 유기용매의 종류와 indole 농도에 따라 최적 생존력 및 indigo 생합성 능력이 다르 게 나타났다. Mesitylene을 제외한 4 종의 유기용매에서 0.5-8 $\mathrm{g} / 1$ 의 indole 존재하에서도 균의 증식이 우수했으며, 특히 propylbenzene과 pxylene을 중층한 배양액에서는 $8 \mathrm{~g} / 1$ 의 고
농도 indole에서도 indole이 들어있지 않은 대조구에 비해 생 육에 크게 차이가 없는 결과를 확인할 수 있었으므로 indole에 대하여 내성이 높은 것으로 확인되었다(Fig. 1). 본 실험결과 $\mathrm{BCNU} 106$ 균주는 고농도 indole 내성 균주인 Pseudomonas sp. strain ST-200과 비교하여도 유사하게 높은 indole에 대한 내성을 나타내는 것으로 확인되었다[6].

각종 농도의 indole에서의 생존과 indole의 변환 정도는 육 안으로 확인할 수 있었으며, indigo와 indirubin 생성 정도도 확인 가능하였다(Fig. 2). Diphenylmethane과 pxylene에서는 $16 \mathrm{~g} / 1$ 농도의 indole에서 생존가능하였고 indigo와 indirubin 을 다소 생성하였으며, $4 \mathrm{~g} / 1$ 와 $8 \mathrm{~g} / 1$ 의 indole 존재하에서 가 장 많은 indigo와 indirubin을 생성함을 확인할 수 있었다(Fig. 2). 또한 indigo, indirubin 및 그 유도체를 생합성할 수 있는 indole의 농도는 유기용매에 따라 차이가 있었으며, pxylene 과 diphenylmethane의 경우 $0.5 \mathrm{~g} / 1$ 에서 $16 \mathrm{~g} / 1$ 로 매우 넓은 농도 범위인 것으로 확인되었고, mesitylene은 $0.5 \mathrm{~g} / 1$ 에서 4 $\mathrm{g} / \mathrm{l}$, propylbenzne은 $1 \mathrm{~g} / 1$ 에서 $8 \mathrm{~g} / 1$ 그리고 toluene은 $2 \mathrm{~g} / 1$ 에서 $8 \mathrm{~g} / 1$ 인 것으로 나타났다. HPLC를 이용하여 정량분석을 실시한 결과, mesitylene과 propylbenzene은 $2 \mathrm{~g} / 1$ 의 indole 첨가시 각각 $216.9 \mathrm{mg} / 1$ 와 $205.1 \mathrm{mg} / \mathrm{l}$ 의 indigo를 생산하였 고, p-xylene은 $4 \mathrm{~g} / 1$ 의 indole을 첨가했을 때 $270.09 \mathrm{mg} / 1$ 의 indigo를 생산함으로써 생산성이 가장 좋은 것으로 확인되었 다. 반면에 indirubin은 $0.5 \mathrm{~g} / 1$ 의 상대적으로 저농도 indole과 $p$-xylene을 첨가했을 때 $62.3 \mathrm{mg} / 1$ 로 생산효율이 좋은 것으로 나타났다(Fig. 3). 최종적으로 indigo 생산 효율이 가장 좋은 pxylene에 대해 indole의 농도와 시간에 따른 생산량 변화를 알아보기 위해 indigo, indirubin 및 isatin의 생산량과 indole 소비량을 측정하였다(Fig. 4). $4 \mathrm{~g} / 1$ 의 indole을 첨가하여 48 시간 배양했을 때 $315.5 \mathrm{mg} / 1$ 의 indigo를 생산하였으며, 96 시간까지 수율이 $276.3 \mathrm{mg} / 1$ 로 높은 수준으로 유지되었다. Indirubin은 $2 \mathrm{~g} /$ 의 indole에서 $48-72$ 시간 배양시 $54.5 \mathrm{mg} / 1$ 로 조사되었으며, indirubin은 pxylene 존재 하에서는 indole

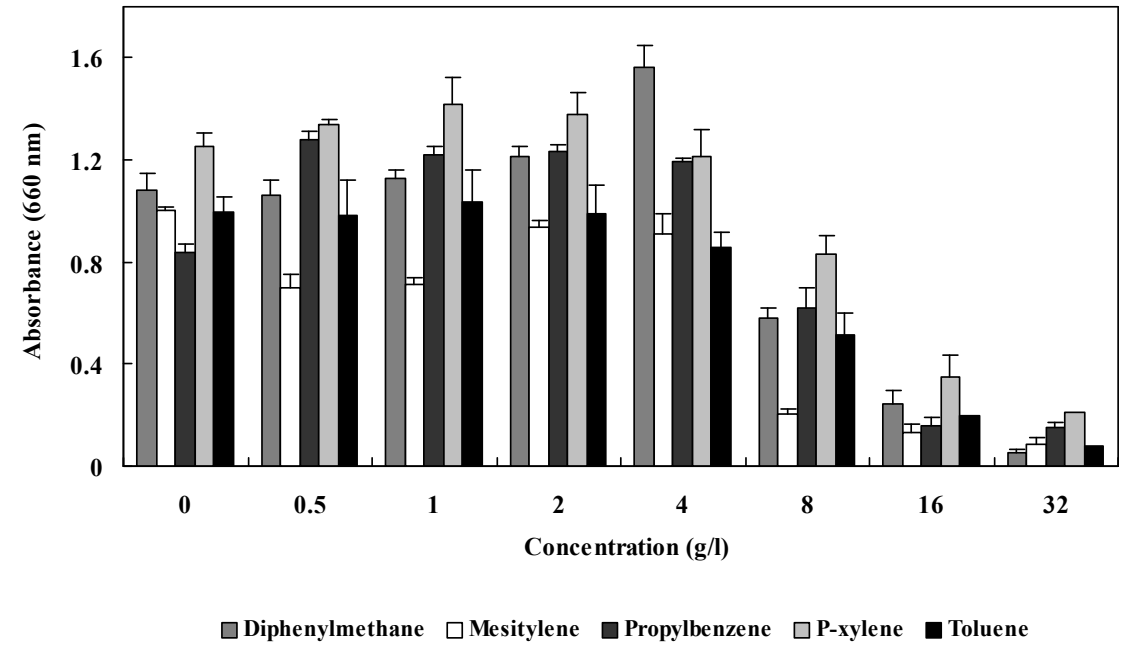

$\square$ Diphenylmethane $\square$ Mesitylene
Fig. 1. Growth of BCNU 106 in the presence of indole $(0.5-32 \mathrm{~g} / \mathrm{l})$ and $20 \%(\mathrm{v} / \mathrm{w})$ various kinds of organic solvents. The growth was measured by optical density at $600 \mathrm{~nm}$ after $24 \mathrm{hr}$ incubation at $30^{\circ} \mathrm{C}$. 

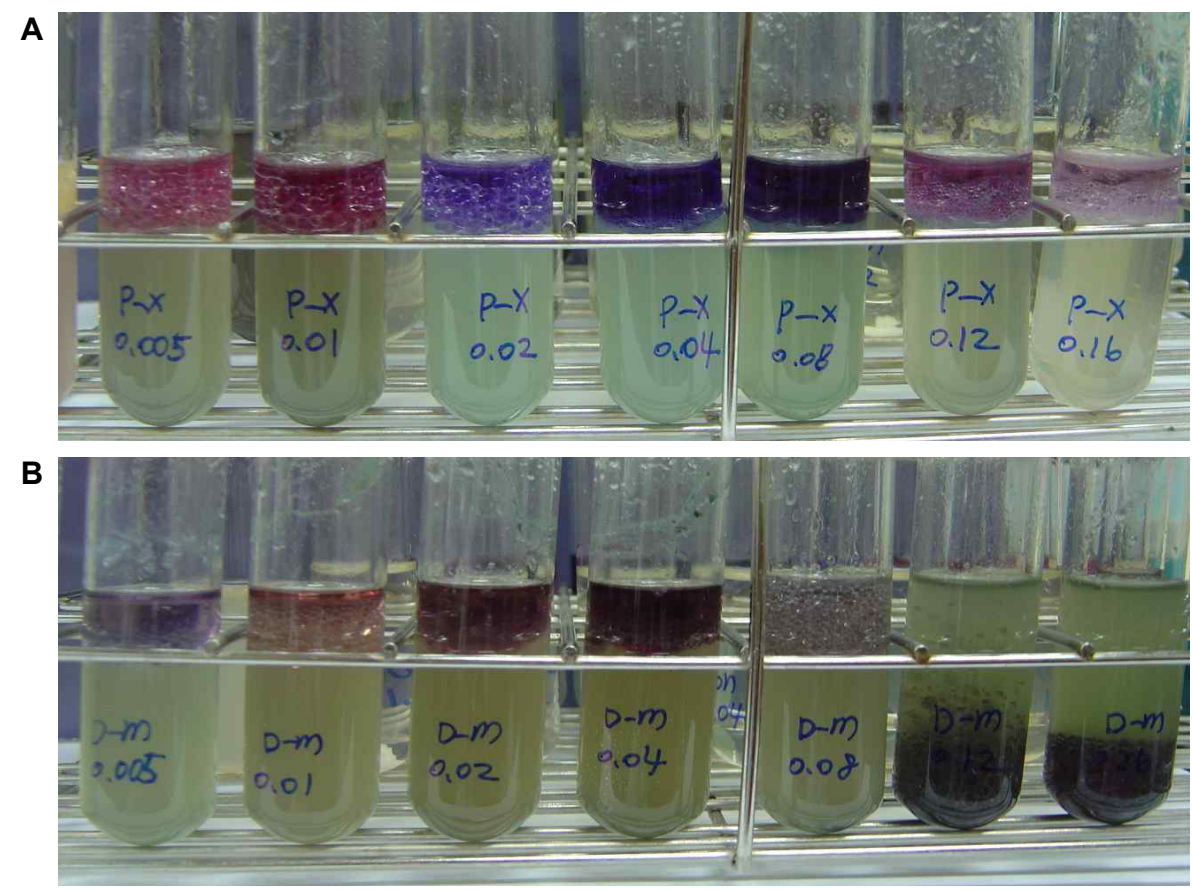

Fig. 2. Production of indigoid pigments from indole by BCNU 106. Indole $(0.5-16 \mathrm{~g} / \mathrm{l})$ was added to conversion medium overlaid with $2 \mathrm{ml}$ of (A) pxylene and (B) diphenylmethane.

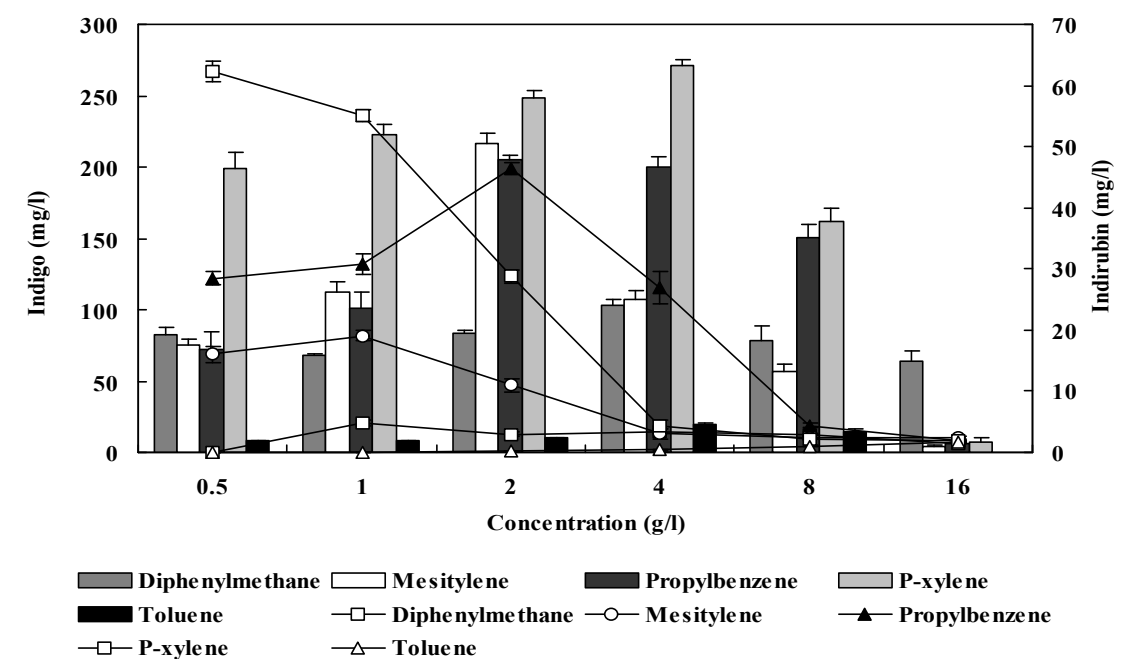

Fig. 3. The bio-indigo and indirubin production by BCNU 106 on indole in the presence of various organic solvent (bar graph, indigo; line graph, indirubin).

농도가 낮을수록 효율이 증가하는 것으로 나타났다.

한편 isatin은 indigo의 생산 조건에서 낮은 비율로 생산되 었으며, indigo 생산량이 서서히 감소하는 48 시간 이후부터 서서히 증가하다가 72 시간 이후로는 다시 감소하는 경향을 보여 산화반응에 의해 isatic acid로 전환됨을 확인할 수 있었 다[11]. 한편 기질인 indole은 처음 24 시간 동안에 급격히 감 소하는 것으로 나타나 초기 효소반응에 의하여 대부분 소모되 는 것으로 확인되었다. Indigo 및 indirubin의 생합성 경로는 indole이 산화되면서 cis-indole-2,3-dihydrodiol이 생성되고, 이 화합물이 산화되어 isatin과 isatic acid를 형성한다. 또한 cis-indole-2,3-dihydrodiol의 자발적인 수소 제거반응에 의해 indoxyl와 oxindole이 생성되며, indoxyl는 공기 중에 산화 되면서 indigo가 형성되고 indoxyl와 oxindole에 의해 indirubin이 생성되는 것으로 보고되어 있다[8]. 본 실험에서도 indigo, indirubin 및 isatin이 유사한 합성경로로 생성되는 것으로 추정된다.

Comamonas sp.는 에너지원과 기질로 각각 $100 \mathrm{ppm}$ 의 naphthalene과 $300 \mathrm{mg} / \mathrm{l}$ 의 indole을 이용하여 $205 \mathrm{mg} / \mathrm{l}$ 의 indigo를 생산하였으며, $1 \mathrm{~g} / 1$ 의 indole 첨가시 indigo 생산 량이 급격히 감소하는 것으로 보고되었다[19]. 일반적으로 고 농도의 indole은 그 독성으로 인해 indigo의 생산을 현저하게 감소시키나, $\mathrm{BCNU} 106$ 은 $8 \mathrm{~g} / \mathrm{l}$ 의 고농도 indole을 첨가시에 

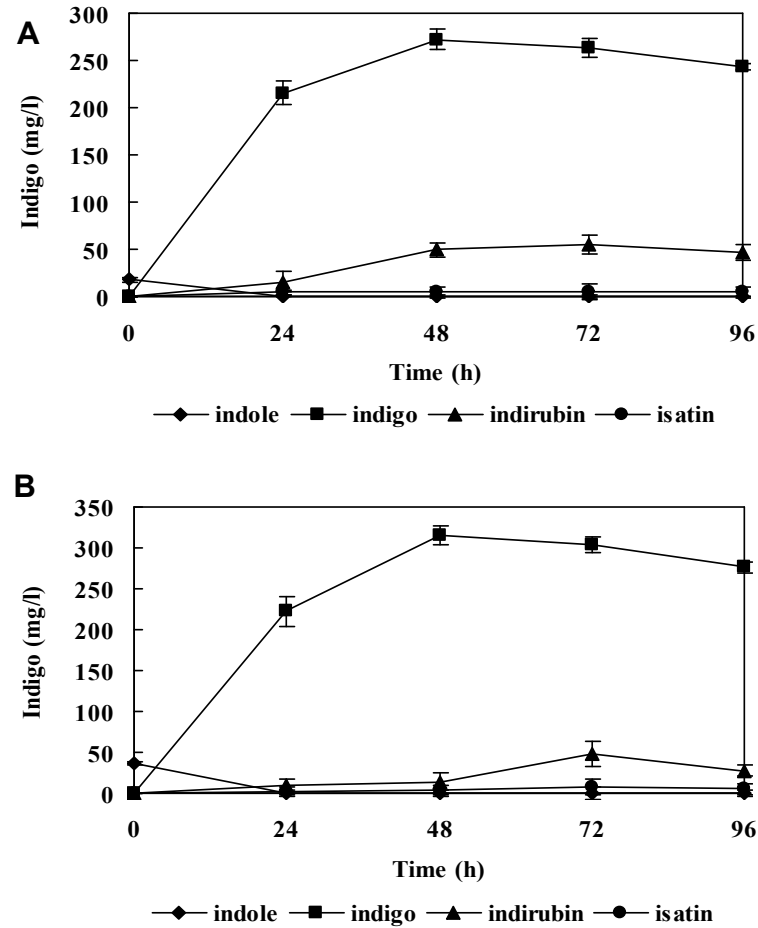

Fig. 4. Production of bio- indigo and indirubin in the presence of indole and p-xylene. BCNU 106 was grown at $30^{\circ} \mathrm{C}$ in $10 \mathrm{ml}$ of conversion medium overlaid with $20 \%$ of pxylene containing (A) $2 \mathrm{~g} / \mathrm{l}$, (B) $4 \mathrm{~g} / 1$ of indole. At time, sample was taken from the organic solvent and water phase of the culture.

도 균의 증식이 우수했으며, indigo 생산효율도 뛰어난 것으로 나타났다. Acinetobacter sp. PP-2는 $203 \mathrm{mg} / 1$ 의 indigo 최적생 산 조건이 $158 \mathrm{ppm}$ 의 phenol과 $205 \mathrm{mg} / 1$ 의 indole인 것으로 보고되고 있으며[16], Pseudomonas sp. QM은 최적조건으로 phenol과 indole을 이용하여 $27.2 \mathrm{mg} / 1$ 의 indigo를 생산하는 것으로 보고되고 있다[17]. 따라서 Pseudomonas sp. BCNU 106 은 호기적인 조건에서 $30^{\circ} \mathrm{C}, 48$ 시간 배양시 $20 \%$ 의 p-xylene 존재 하에서 $4 \mathrm{~g} / 1$ 의 indole을 이용하여 $315.5 \mathrm{mg} / 1$ 의 indigo 를 생산함으로써 생합성 능력이 매우 뛰어난 균주임을 확인할 수 있었다. 또한 indole 유도체의 주요 생성물인 indigo와 indirubin 이외에도 다양한 pigments가 관찰되어 배양온도, 기 질농도와 용매 등에 따라 이들 indole 유도체의 생산을 조절할 수 있을 것으로 판단되어, 보다 자세한 연구를 통해 산업적으 로 다양한 indole 유도체 생성에 BCNU 106 균주를 활용 가능 할 것으로 판단된다. 현재 indole 유도체의 다양한 기능에 대 한 연구가 활발히 이뤄지고 있으며, 최근 alkaloid indigo의 알코올성 산화적 손상에 대한 기능이 보고되었고[10], isatin과 그 유도체는 항고혈압, 항균, 항종양 및 항염증 등의 기능이 보고되어 의약화학 분야에서 활발히 응용되고 있으며[2], indirubin은 백혈병을 비롯한 항암치료, 알쯔하이머와 같은 뇌 조직 퇴화 관련 질병 치료에 효과가 매우 높은 것으로 알려져
있다[8, 12].

한편 유기용매 내성Pseudomonas sp. BCNU 106 균주를 사 용한 persolvent fermentation에 의한 indole 변환반응은 독성 물질인 indole 변환반응에 유기용매를 사용함으로써 고농도 의 indole이 배지에는 적게 공급되도록 하고 있다 $[9,12,18]$. 특히 BCNU 106 균주는 two-phase system에서 지속적으로 생물변환반응을 수행하면서도 세포독성은 회피할 수 있는 내 성 균주로서 보다 많은 기질을 이용한 변환 반응을 수행하는 데 유용한 생물자원이므로 산업적인 면에서 보다 광범위한 활용방안에 대한 추가적인 연구가 요구된다.

\section{감사의 글}

본 연구는 한국연구재단 기본연구지원사업(과제번호: 20100009141)에 의해 지원되었으므로 이에 감사드립니다.

\section{References}

1. Angelini, L. G., Tozzi, S. and Nassi o Di Nasso, N. 2004. Environmental factors affecting productivity, indican content, and indigo yield in Polygonum tinctorium Ait., a subtropical crop grown under temperate conditions. J Agric Food Chem 52, 7541-7547.

2. Bhrigu, B., Pathak, D., Siddiqui, N., Alam, M. S. and Ahsan, W. 2010. Search for biological active isatins: a short review. Int J Pharm Sci Drug Res 2, 229-235.

3. Bhushan, B., Samanta, S. K. and Jain, R. K. 2000. Indigo production by naphthalene degrading bacteria. Lett Appl Microbiol 31, 5-9.

4. Choi, H. J., Seo, J. Y., Hwang, S. M., Lee, Y. I., Jeong, Y. K., Moon, J. Y. and Joo, W. H. 2013. Isolation and characterization of BTEX tolerant and degrading Pseudomonas putida BCNU 106. Biotechnol Bioprocess Eng 18, 1000-1007.

5. Cooksey, C. J. 2007. Indigo: an annotated bibliography. Biotechnic Histochem 82, 105-125.

6. Doukyu, N. and Aono, R. 1997. Biodegradation of indole at high concentration by persolvent fermentation with Pseudomonas sp. ST-200. Extremophiles 1, 100-105.

7. Doukyu, N., Toyoda, K. and Aono, R. 2003. Indigo production by Escherichia coli carrying the phenol hydroxylase gene from Acinetobacter sp. strain ST-550 in a water organic solvent two-phase system. Appl Microbiol Biotechnol 60, 720-725.

8. Eaton, R. W. and Chapman, P. J. 1995. Formation of indigo and related compounds from indolecarboxylic acids by aromatic acid-degrading bacteria: chromogenic reactions for cloning dioxygenases that act on aromatic acids. J Bacteriol 177, 6983-6988.

9. Ensley, B. D., Ratzkin, B. J., Osslund, T. D., Simon, M. J., Wackett, L. P. and Gibson, D. T. 1983. Expression of naphthalene oxidation genes in Escherichia coli results in the biosynthesis of indigo. Science 222, 167-169. 
10. Farias-Silva E., Cola, M., Calvo, T. R., Barbastefano, V., Ferreira, A. L., De Paula Michelatto, D., Alves de Almeida, A. C., Hiruma-Lima, C. A., Vilegas, W. and Brito, A. R. 2007. Antioxidant activity of indigo and its preventive effect against ethanol-induced DNA damage in rat gastric mucosa. Planta Med 73, 1241-1246.

11. Gillam, E. M. J., Notley, L. M., Cai, H., De Voss, J. J., Guengerich, F. P. 2000. Oxidation of indole by cytochrome P450 enzymes. Biochemistry 39, 13817-13824.

12. Madsen, E. L. and Bollag, J. M. 1988. Pathway of indole metabolism by a denitrifying microbial community. Arch Microbiol 151, 71-76.

13. Murdock, D., Ensley, B. D., Serdar, C. and Thalen, M. 1993. Construction of metabolic operons catalyzing the de novo biosynthesis of indigo in Escherichia coli. Biotechnol 11, 381386.

14. Gilbert, K. G., Hill, D. J., Crespo, C., Mas, A., Lewis, M., Rudolph, B. and Cooke, D. T. 2000. Qualitative analysis of indigo precursors from woad by HPLC and HPLC-MS. Phytochem Anal 11, 18-20.
15. Puchalska, M., Polec-Pawlak, K., Zadrozna, I., Hryszko, H. and Jarosz, M. 2004. Identification of indigoid dyes in natural organic pigments used in historical art objects by high-performance liquid chromatography coupled to electrospray ionization mass spectrometry. J Mass spectrom 39, 1441-1449.

16. Qu, Y., Pi, W., Ma, F., Zhou, J. and Zhang, X. 2010. Influence and optimization of growth substrates in indigo formation by a novel isolate Acinetobacter sp. PP-22. Bioresour Technol 101, 4527-4532

17. Qu, Y., Ma, Q., Zhang, X., Zhou, H., Li, X. and Zhou, J. 2012. Optimization of indigo production by a newly isolated Pseudomonas sp. QM. J Basic Microbiol 52, 687-694.

18. Schmid, A., Dordick, J. S., Hauer, B., Kiener, A., Wubbolts, M. and Witholt, B. 2001. Industrial biocatalysis today and tomorrow. Nature 409, 258-268.

19. Zhang, X., Qu, Y., Ma, Q., Zhoi, H., Li, X., Kong, C. and Zhou, J. 2013. Cloning and expression of naphthalene dioxygenase genes form Comamonas sp. MQ for indigoids production. Process Biochem 48, 581-587.

초록 : Pseudomonas sp. BCNU 106의 persolvent fermentation에 의한 인디고이드계 색소 생산

최혜정 ${ }^{1} \cdot$ 권기석 $^{2} \cdot$ 주우홍 ${ }^{1} \star$

('창원대학교 생물학과 - 생물공학협동과정, ${ }^{2}$ 안동대학교 생명자원과학부)

산업폐수로부터 분리한 Pseudomonas sp. BCNU 106은 다양한 유기용매를 이용하여 인돌로부터 인디고를 합성 할 수 있다. BCNU 106은 높은 수준의 인돌과 다량의 pxylene, propylbenzene 그리고 mesitylene의 존재 하에서 효과적으로 인디고를 생산했다. 본 연구에서 인디고의 최대수율 조건은 $20 \%(\mathrm{v} / \mathrm{w})$ 의 $p$-xylene과 $4 \mathrm{~g} / 1$ 의 인돌인 것으로 확인되었다. 이러한 조건에서 인디고의 수율과 인돌의 전환효율은 각각 $315.5 \mathrm{mg} / 1$ 와 $97 \%$ 로 조사되었다. 그 결과 Pseudomonas sp. BCNU 106은 산업적으로 중요한 인디고 생산을 위한 잠재적인 균주가 될 것으로 판단된 다. 